\title{
HUKUM DALAM MENDORONG DINAMIKA PEMBANGUNAN PEREKONOMIAN NASIONAL DITINJAU DARI PRINSIP EKONOMI KERAKYATAN
}

\author{
Dwi Ratna Indri Hapsari \\ Fakultas Hukum Universitas Muhammadiyah Malang \\ J1. Raya Tlogomas No. 246 Malang \\ E-mail : Indri3009@gmail.com
}

\begin{abstract}
Article 33 paragraph (4) of the 1945 Indonesian Constitution, "The national economy which is regulated based on economic democracy with the principle of togetherness, efficiency, justice, support, environmental insight, independence, and also with financial assistance in various large business activities, cheap, and small in the business partnership pattern ". The concept of the Indonesian national economy commenting on us together and explicitly in our constitution adhering to the principle of kinship agreed upon can be found in Article 33 paragraph (4) of the 1945 Indonesian Constitution, people's sovereignty also promotes Pancasila. As a developing country Indonesia cannot escape the era of globalization, international free trade. However, what makes the challenge is that Indonesia can still keep up with the flow of globalization but still in the populist economic corridor that has been conceptualized in the state constitution concerning national economic development. Law in this case has a special stake in efforts to grow the economy of a country in order to achieve national economic development.
\end{abstract}

Keywords: Law, Economy, Populist

\begin{abstract}
Abstrak
Pasal 33 ayat (4) Undang-Undang Dasar Negera Republik Indonesia 1945 menyatakan bahwa, "Perekonomian nasional diselenggarakan berdasarkan demokrasi ekonomi dengan prinsip kebersamaan, efisien, berkeadilan, berkelanjutan, berwawasan lingkungan, kemandirian, serta dengan menjaga keseimbangan dalam kegiatan usaha besar, menengah, dan kecil dalam pola kemitraan usaha". Konsep ekonomi nasional Indonesia sebagaimana kita pahami bersama dan tersurat pula dalam konstitusi kita menganut asas kekeluargaan sebagaimana dapat dijumpai pada Pasal 33 ayat (1) Undang - Undang Dasar Negera Republik Indonesia 1945, berkedaulatan rakyat serta bermoralkan pancasila. Sebagai negara berkembang Indonesia tidak juga dapat melepaskan diri dari pengaruh era globalisasi, perdagangan bebas secara internasional. Namun demikian yang menjadikan tantangan adalah bagaimana Indonesia tetap dapat menikuti arus globalisasi namun tetap berada pada koridor ekonomi kerakyatan yang telah terkonsep dalam konstitusi negara sekalipun berupaya dalam pembangunan ekonomi nasional. Hukum dalam hal ini memiliki andil tersendiri dalam upaya menumbuhkan ekonomi suatu negara guna mencapai pembangunan ekonomi nasional.
\end{abstract}

Kata Kunci: Hukum, Ekonomi, Kerakyatan 


\section{A. PENDAHULUAN}

Beberapa negara di dunia menganut paham welfare state (negara kesejahteraan) dan menjadikannya sebagai tujuan bernegara begitupun Indonesia. Salah satu upaya dalam mewujudkan welfare state adalah melalui pembangunan ekonomi nasional. Landasan pembangunan ekonomi nasional Indonesia dapat kita temukan dalam Undang-Undang Dasar Negera Republik Indonesia 1945 sebagai grundnorm dan Pancasila dalam kedudukannya sebagai staat fundamental norm. Hukum dalam hal ini memiliki andil tersendiri dalam upaya menumbuhkan ekonomi suatu negara guna mencapai pembangunan ekonomi nasional. Hukum sangat berperan dalam menunjang pertumbuhan ekonomi Indonesia. ${ }^{1}$

Sebagai alat rekayasa sosial sebagaimana telah terlahir dari konsep pemikiran Roscoe Pound, hukum yang berkembang dalam masyarakat memiliki peran sesuai dengan fungsinya sehingga dapat berpengaruh dalam pembangunan ekonomi sebagaimana telah dikemukakan oleh Gunarto Suhardi. ${ }^{2}$ Pembangunan ekonomi dan pembangunan hukum harus sejalan agar fungsi dan peran hukum dapat mengakomodir ketentuan - ketentuan yang harus diatur oleh bidang perekonomian. Sebagai contoh, guna menunjang perekonomian nasional Indonesia tak dapat menutup diri dari era pasar global sehingga ketentuan yang disepakati secara internasional harus pula diakomodir oleh ketentuan hukum di Indonesia.

Tudung Mulya Lubis percaya bahwa globalisasi dapat dipungkiri lagi memiliki pengaruh yang besar pada negara - negara di dunia. Hukum bisnis khususnya, yang berkembang sejalan dengan berkembangnya jaman global perlu didukung oleh instrumen instrumen hukum yang dapat mengakomodir pesatnya perkembangan dunia bisnis yang tak jarang pula mengadopsi instrumen hukum negara - negara lain yang pastinya tetap harus disesuaikan dengan karakteristik bangsa Indonesia. ${ }^{3}$ Indonesia telah melakukan ratifikasi beberapa perjanjian - perjanjian internasional yang merupakan buah dari ketentuan yang disepakati bersama diantaranya melalui General Agreement on Tariff and Trade (GATT) atau World Trade Organization (WTO). Bahkan belakangan ini Pemerintah Indonesia merampungkan proses ratifikasi Perjanjian Perdagangan Internasional yang tercatat ada 7 (tujuh) diantaranya adalah:

1. First Protocol to Amend the AANZFTA Agreement;

2. Agreement on Trade in Services under the ASEAN-India Free Trade Area AITISA;

3. Third Protocol to Amend the Agreement on Trade in Goods under ASEAN - Korea Free Trade Area / AKFTA;

4. Protocol to Amend the Framework Agreement under ASEAN - China Free Trade Area / ACFTA;

\footnotetext{
1 Dewa Ayu, M. K. P. S dan I Gusti, N. P, "Fungsi Hukum dalam Pembangunan Ekonomi", file:///C:/Users/user/Downloads/6246-10303-1-SM.pdf.Hal:1-2., (Diakses pada 13/1/2019).

${ }^{2}$ Gunarto Suhardi, 2002, Peranan Hukum Dalam Pembangunan Ekonomi, Universitas Atmajaya, Yogyakarta: 2002, hlm. 27.

3 T. Mulya Lubis, ed.Peran Hukum dalam Perekonomian di Negara Berkembang, Yayasan Obor Indonesia, Jakarta,1986, hlm. 72 .
} 
5. ASEAN Agreement on Medical Device Directive/AMDD;

6. Protocol to Implement the 9th ASEAN Framework Agreement on Services/AFAS-9; dan,

7. Protocol to Amend Indonesia - Pakistan PTA/IP-PTA.

Perjanjian Perdagangan Internasional tersebut memberikan pengaruh besar pada Indonesia dan dapat memberikan akses pasar baik barang maupun jasa. Meskipun demikian pada proses ratifikasi Perjanjian Perdagangan Internasional tersebut mendapatkan kritik dari beberapa pihak terkait kurang transparannya proses ratifikasi tersebut. ${ }^{4}$ Ratifikasi tersebut merupakan globalisasi hukum yang dilakukan oleh negara - negara peratifikasi.

Indonesia sebagai negara berkembang memiliki karakteristik yang tentunya berbeda dengan negara - negara berkembang lain. Dengan melakukan ratifikasi perjanjian internasional bidang perdagangan tidak menutup kemungkinan membuahkan hasil yang berbeda dibandingkan negara - negara lainnya. Friedman mengatakan bahwa budaya hukum suatu masyarakat mempengaruhi tegaknya hukum dalam masyarakat tersebut. Faktor - faktor yang mempengaruhi hal tersebut antara lain adalah politik, letak geografis, latar belakang pendidikan, budaya, lingkungan dan yang tidak kalah penting adalah ekonomi. ${ }^{5}$

Dampak terisolasinya suatu bangsa oleh dunia internasional sangat merugikan bangsa tersebut. Oleh karenanya sebagai negara berkembang Indonesia pun harus dapat menyesuaikan diri dengan arus era globalisasi agar tidak semakin tertinggal dengan negara negara lain. Indonesia dituntut untuk dapat bersaing dengan negara - negara lain di dunia agar pembangunan ekonomi di Indonesia dapat menuju ke arah yang lebih baik dengan mengikuti rules yang ada. Awal tahun 2007, Yayasan Indonesia Forum menyampaikan Visi Indonesia Tahun 2030 pada Presiden dan ditargetkan bahwa pendapatan perkapita Indonesia akan mencapai 18.000 dolar Amerika Serikat per tahunnya. Jumlah penduduk Indonesia per tahun 2017 tercatat lebih dari 261 juta orang, ${ }^{6}$ dengan demikian kekuatan ekonomi dunia urutan ke lima setelah Cina, Amerika Serikat, Uni Eropa dan India dapat dengan mudah diduduki oleh Indonesia ${ }^{7}$.

Optimisme menduduki kekuatan ekonomi dunia ke lima pun dibarengi oleh kontadiksi pendapat, melihat kondisi ekonomi Indonesia yang belum mampu menekan angka kemiskinan dan penggangguran serta minimnya investasi. Terpuruknya kondisi ekonomi Indonesia juga dilihat dari tingginya angka korupsi serta menurunnya angka kredibilatas penegak hukum dan lembaga negara. Sebuah buku Social control through law yang lahir dari buah pemikiran

\footnotetext{
${ }^{4}$ Fitri N. Heriani, "Tujuh Perjanjian Perdagangan Indonesia Ini akah diratifikasi oleh Indonesia” 2018, https://www.hukumonline.com/berita/baca/lt5bea2c400d717/7-perjanjian-perdagangan-internasional-ini-akandiratifikasi-indonesia.diakses (Diakses pada 22/2019).

5 Maryanto, "Pengaruh Globalisasi dalam Pembangunan Ekonomi Indonesia", 2011 http://maryanto.blog.unissula.ac.id/2011/10/07/pengaruh-globalisasi-terhadap-hukum-ekonomiindonesia/.diakses. (Diakses pada 22/1/2019).

${ }^{6}$ Statistical year of Indonesia 2018 Katalog 1101001 Badan Pusat Statistik Indonesia.

7 Adi Sulistyono dan Muhammad Rustamaji, Hukum Ekonomi sebagai Panglima, Masmedia Buana Pustaka, Sidoarjo: 2009, hlm. 1.
} 
Roscoe Pound memaknai hukum sebagai metode yang berpengaruh kepada perubahan hubungan social manusia bermasyarakat atau yang dikenal hukum sebagai alat rekayasa sosial "law as a tool of social engineering".

Berangkat dari hal tersebutlan kiranya hukum memiliki peranan yang sangat penting guna mendorong pertumbuhan ekonomi bangsa Indonesia. Sebagai penerus bangsa yang turut prihatin juga menerima kenyataan bahwa Indonesia telah menghadapi krisis masa depan bangsa, peneliti ingin terlibat juga dalam memberikan kontribusi pemikiran melalui peran hukum dalam mendorong dinamika pembangunan perekonomian Indonesia.

Sesuai dengan amanat Pasal 33 ayat (4)Undang-Undang Dasar Negera Republik Indonesia 1945 menyatakan bahwa perekonomian nasional diselenggarakan berdasarkan asas demokrasi ekonomi dengan prinsip kebersamaan, efisiensi berkeadilan, berkelanjutan, berwawasan lingkungan, kemandirian serta dengan menjaga keseimbangan kemajuan dan kesatuan ekonomi nasional, Indonesia memiliki jati diri yang termaktub dalam konstitusi yang menjadi landasan dalam pembangunan perekonomian nasional.

Atas dasar pemikiran tersebut maka peneliti ingin melakukan kajian lebih mendalam mengenai perah hukum dalam mendorong dinamika pembangunan perekonomian nasional ditinjau dari prinsip ekonomi kerakyatan melalui beberapa pembahasan mengenai urgensi pembangunan hukum ekonomi nasional, peran hukum dalam mendorong dinamika pembangunan perekonomian nasional ditinjau dari prinsip ekonomi kerakyatan, serta strategi pembangunan perekonomian nasional dengan berprinsip ekonomi kerakyatan.

\section{B. PEMBAHASAN}

\section{Hukum Ekonomi}

Para pakar/ahli hukum memiliki pendapat yang berbeda - beda mengenai definisi hukum. Pendapat tersebut mencerminkan bahwa memang belum ada kesatuan pendapat atau unifikasi untuk memaknai kata "hukum" oleh para pakar/ahli hukum. Sebagaimana Utrecht berpendapat bahwa hukum merupakan kumpulan aturan baik berupa perintah maupun larangan yang memaksa masyarakat yang dikenai oleh hukum tersebut untuk patuh dan menaatinya. Meyers mengemukakan bahwa hukum itu ditujukan kepada tingkah laku manusia dalam suatu masyarakat sehingga didalamnya harus mengandung pertimbangan kesusilaan agar dapat menjadi pedoman para penguasa negara untuk melaksanakan tugasnya ${ }^{8}$. M. T. Cicero percaya bahwa hukum merupakan the highest reason yang tertanam sebagai kontrol terhadap manusia mengenai perilaku yang boleh tidaknya dilakukan oleh manusia. Sementara Rudolf von Jhering mengakui bahwa hukum merupakan aturan - aturan yang bersifat memaksa.

Berbagai definisi hukum lahir atas pendapat para pakar/ahli hukum tersebut diatsa dapat penulis simpulkan bahwa hukum itu terdiri dari unsur - unsur: aturan tentang tingkah laku masyarakat; dibuat oleh pejabat yang berwenang; hukum berisi perintah dan larangan

\footnotetext{
${ }^{8}$ Abdul R. saliman, Hukum Bisnis untuk Perusahaan :Teori dan Contoh Kasus, Prenadamedia Group, Jakarta: 2015, hlm. 7 .
} 
yang memiliki sifat memaksa; serta ada sanksi yang tegas bagi para pelanggarnya. Menukil pendapat Mochtar Kusumaatmadja bahwa hukum berfungsi menyediakan jalur yang menunjang pembangunan suatu bangsa terlebih pembangunan ekonominya. Sehingga demikian hukum tak dapat dimaknai secara definitif melainkan secara fungsional juga.

Sistem ekonomi kapitalis dewasa ini mendominasi perekonomian dunia yang kemudian berpengaruh pada kebijakan - kebijakan ekonomi dunia. Meskipun terdapat pula sistem ekonomi sosialis yang dianut oleh beberapa negara di dunia namun sistem ekonomi kapitalis tetap menjadi kiblat sistem hukum ekonomi dunia sebagai bukti lahirnya General Agreement on Tariff and Trade (GATT), World Trade Organitation (WTO), International Moneter Fund (IMF).

Rochmat Soemitro berpendapat bahwa pemerintah menciptakan suatu norma yang mengatur kehidupan masyarakat pada aspek ekonomi sebagai suatu wujud dari masyarakat. Sementara Soedarto mendefinisikan hukum ekonomi sebagai keseluruhan peraturan atau kaidah kaidah hukum dalam sektor perekonomian. Dengan demikian, "pengertian hukum ekonomi merupakan keseluruhan kaidah hukum yang mengatur dan mempengaruhi segala sesuatu yang berkaitan dengan kehidupan perekonomian nasional negara, baik itu kaidah hukum yang bersifat privat maupun yang bersifat publik, tertulis maupun tidak tertulis, yang mengatur kegiatan serta kehidupan perekonomian nasional negara".

Semakin pesatnya pertumbuhan ekonomi menyumbang lahirnya hukum ekonomi yang berfungsi membatasi dan mengatur kegiatan - kegiatan ekonomi suatu negara bahkan lintas batas negara dengan tetap mempertimbangkan kepentingan dan juga hak - hak dari masyarakat. Perlindungan terhadap hak dan kepentingan warga negara merupakan kewajiban pemerintah demi mencapai suatu tujuan yakni negara kesejahteraan atau Welfare state.

Bentuk perlindungan terhadap hak dan kepentingan masyarakat terwujud melalui hukum formal yang bertujuan untuk mencapai pembangunan ekonomi nasional melalui kebijakan - kebiakan pemerintah yang tertuang dalam hukum formal tersebut. Sehingga peningkatan taraf hidup masyarakat Indonesia tidak mustahil untuk tercapai.

Perbedaan pendapat mengani hukum ekonomi sebagaimana dikemukakan oleh Rachmadi Usman terkait sifat publik atau privat-nya kaidah - kaidah dalam hukum ekonomi yang mengatur kehidupan ekonomi suatu negara bukanlah hal yang perlu untuk dikhawatirkan mengingat urgensi dari hukum sendiri untuk berperan dalam meningkatkan pembangunan ekonomi nasional tanpa melihat sifat dari kaidah hukum itu sendiri. ${ }^{9}$ Terkait kedudukan hukum ekonomi apakah menjadi cabang ilmu hukum ataukah cabang ilmu ekonomi tidaklah perlu menjadi perdebatan yang berkepanjangan karena pada hakekatnya sebperti yang telah penulis sampaikan sebelumnya bahwa sistem hukum dan sistem ekonomi memiliki hubungan yang erat.

\section{Prinsip Ekonomi Kerakyatan di Indonesia}

\footnotetext{
${ }^{9}$ Rachmadi Usman, Hukum Ekonomi dalam Dinamika, Djambatan, Jakarta: 2014, hlm. 56.
} 
Peningkatan kemampuan masyarakat dalam mengendalikan jalannya roda perekonomian merupakan tujuan bangsa Indonesia yang seirama dengan jati diri bangsa Indonesia yang menganut asas kekeluargaan sebagai suatu sistem ekonomi kerakyatan ${ }^{10}$. Mubaryo yang menuangkan pemikirannya dalam buku "Reformasi Sistem Ekonomi: dari Kapitalis Menuju Ekonomi Kerakyatan", berpendapat bahwa ekonomi kerakyatan merupakan ekonomi yang demokratis yang bertujuan untuk dapat memberikan kemakmuran khususnya pada rakyat kecil ${ }^{11}$. Keberpihakan kepada ekonomi rakyat dipercayai oleh Zulkarnain merupakan aspek penting yang harus dianut selain keadilan dan demokrasi ekonomi ketika suatu negara menggunakan sistem ekonomi kerakyatan yang sesuai dengan falsafah negara ${ }^{12}$

Djamester A. Simarmata menafsirkan demokrasi ekonomi setara dengan ekonomi kerakyatan yang dianut oleh bangsa Indonesia. Definisi ekonomi kerakyatan dapat kita temukan dalam penjelasan Pasal 33 Undang - Undang Dasar Negara Republik Indonesia 1945 bahwa ekonomi kerakyatan merupakan system ekonomi yang mana semua lapisan masyarakat memiliki kontribusi dalam proses produksi dikerjakan oleh semua dan anggota masyarakat berkesempatan untuk memilikinya. Sehingga, tercapainya suatu demokrasi ekonomi dapat ditandai dengan keikutsertaan anggota - anggota masyarakat dalam setiap kegiatan produksi. ${ }^{13}$

Dengan memperhatikan pelaku Usaha Mikro, Kecil dan Menengah (UMKM) dalam kaitannya kegiatan ekonomi, itu berarti pemahaman mengenai ekonomi kerakyatan mulai terbentuk. Sehingga pelaku ekonomi berskala kecil akan lebih terberdayakan. Selain kegiatan ekonomi, pendekatan sistem ekonomi dengan menganut demokrasi ekonomi juga perlu selalu dikembangkan sehingga dalam segala kegiatan ekonomi akan memperhatikan demokrasi ekonomi.

Sistem ekonomi kerakyatan secara sederhana dapat dimaksani sebagai upaya pelibatan seluruh lapisan masyarakat sebagai motor penggerak pembangunan nasional. Dengan demikian prinsip - prinsip demokrasi ekonomi dapat terimplementasikan dengan baik untuk mendorong pembangunan nasional. ${ }^{14}$

Kesejahteraan rakyat Indonesia merupakan buah dari penerapan ekonomi kerakyatan yang menyertakan seluruh lapisan masyarakat dalam proses produksi sehingga keadilan, demokrasi ekonomi, keberpihakan pada ekonomi rakyat terwujud. Meskipun masih sangat jauh untuk dapat disebut sebagai negara kesejahteraan namun dengan komitmen bersama dan semangat untuk mewujudkannya niscaya akan berbuah manis. Pancasila serta Pasal 27 ayat (2), 28, 31, 33 serta 34 Undang-Undang Dasar Negera Republik Indonesia 1945

\footnotetext{
${ }^{10}$ Baswir Revrisond, Tiada Ekonomi Kerakyatan Tanpa Kedaulatan Rakyat, Pustaka Pelajar, Yogyakarta: 1995, hlm. 20.

11 Mubaryo, Reformasi Sistem Ekonomi: Dari Kapitalis Menuju Ekonomi Kerakyatan, Aidtya Media, Yogyakarta, 1999, hlm..81.

${ }^{12}$ Zulkarnain, Kewirausahaan (Strategi Pemberdayaan Usaha Kecil Menengah Dan

Penduduk Miskin), Adicita Karya Nusa ,Yogyakarta: 2006, hlm. 98.

${ }^{13}$ Simarmata, D. A, Reformasi Ekonomi, Lembaga Penerbit Fakultas Ekonomi UI, Jakarta: 1998, hlm. 117.

${ }^{14}$ A. Z. Fachri Yasin, dkk, Petani, Usaha Kecil Dan Koperasi Berwawasan Ekonomi Kerakyatan, Unri Press, Pekanbaru: 2002, hlm.2-3.
} 
merupakan landasan hukum yang sangat tepat sesuai dengan amanat founding fathers Bangsa Indonesia. Sebagai landasan ideologis serta sistem nilai suatu bangsa, Pancasila dapat mewujudkan keadilan sosial bagi seluruh rakyat Indonesia.

\section{Pembangunan Hukum Ekonomi Indonesia}

Negara Indonesia adalah negara hukum (rechtsstaat) bukan negara kekuasaan (machtsstaat). Kalimat tersebut kita temukan dalam Pasal 1 Ayat (3) Undang - Undang Dasar Negara Republik Indonesia Tahun 1945 serta dijelaskan dalam pasal - pasal penjelasannya. Praktek penyelenggaraan negara lahir dari Konsep negara hukum yang mendudukkan hukum sebagai panglima.

Konsep negara hukum melekat erat sebagai landasan secara konstusional yang mewajibkan setiap warga negara menaati hukum dan penegakan /supremasi hukum harus dilaksanakan. Dapat dibayangkan bagaimana jika hukum tidak pernah lahir di tengah tengah masyarakat. Tentunya suatu bangsa akan mengalami suatu kondisi chaos. Tujuan hukum berupa kepastian hukum, keadilan serta kemanfaatan hanya akan terwujud apabila kehidupan masyarakat terdapat seperangkat aturan hukum ${ }^{15}$.

Hampir semua orang memahami bahwa kegiatan ekonomi berujung pada meuntungan/laba/profit. Sehingga prinsip klasik kegiatan ekonomi yang menghendaki keuntungan sebesar - besarnya dengan modal sekecil - kecilnya sangat berbeda secara prinsip dengan hukum yang bersifat membatasi tindakan serta perilaku manusia. Itulah sebabnya mitos yunani kuno memandang ekonomi dan hukum secara prinsip adalah hal yang berbeda dan saling kontradiksi. Pandangan tersbut menurut penulis tidaklah selamnya benar, karena hukum dan ekonomi seperti dijelaskan sebelumnya memiliki kaitan erat dan saling melengkapi dalam tujuan yang sama pembangunan nasional.

Tolak ukur yang dapat digunakan untuk menentukan suatu bangsa itu termasuk bangsa berkembang ataukah bangsa maju (developed countries) adalah dengan melihat tingkat hidup masyarakatnya. Sehingga pembangunan ekonomi gencar dilakukan oleh negara berkembang untuk dapat meningkatkan taraf hidup masyarakatnya. ${ }^{16}$ Namun demikian, lahirnya Bank Dunia (World Bank),Dana Moneter Internasional (The International Monetary Fund/MMF) serta Persetujuan Umum tentang Tarif dan Perdagangan (The General Agreement on Tariffs and Trade/GATT) justru membuat negara berkembang semakin tergantung pada negara maju bukan malah menyusul yang sebelumnya developing countries menjadi developed countries.

Keberpihakan Bank Dunia (World Bank),Dana Moneter Internasional (The International Monetary Fund/IMF) serta Persetujuan Umum tentang Tarif dan Perdagangan (The General Agreement on Tariffs and Trade/GATT) kepada negara negara maju melalui kebijakan ekonomi yang dilahirkan justru akan semakin menguntungkan negara - negara maju tersebut. Menurut pendapat Prof. Dr. W. Verwey

\footnotetext{
${ }^{15}$ Aminuddin Ilmar, Konstruksi Teori dan Metode Kajian Ilmu Hukum, Hasanuddin University Press, Makassar: 2009, hlm. 3.

${ }^{16}$ Y. Sri Susilo, Peranan Hukum dalam Pembangunan Ekonomi, Universitas Atma Jaya Yogyakarta (UAJY), Yogyakarta: 2002, hlm.1.
} 
beberapa prinsip ekonomi internasional yang sifatnya klasik banyak diterapkan seperti perdagangan bebas (free trade), kesetaraan (equality), reciprocity yang mengakibatkan industri kecil atau usaha mikro kecil dan menengah tak mampu menyaingi industri kelas besar berskala internasional bahkan di dalam negeri karena telah menguasai pasar dan semua itu atas nama free trade, equality, reciprocity. Hal tersebut lambat laun akan mematikan industri kecil, mikro menengah dalam negeri dan menjadikan negara berkembang akan sangat bergantung pada negara maju ${ }^{17}$. Buktinya adalah masuknya usaha ritel modern di Indonesia yang berasal dari luar negeri ataupun dalam negeri sendiri yang dikuasai oleh beberapa orang saja sudah pasti mengalahkan ritel tradisional. Di beberapa daerah di Indonesia hal tersebut sudah menjadi pemandangan sehari - hari sehingga ritel tradisional yang memiliki karakteristik yang berbeda dengan ritel modern semakin lesu dan mati dengan sendirinya.

Konsep welfare state mengaharuskan pemerintah intervensi dalam kehidupan ekonomi rakyatnya. Intervensi tersebut terwujud dalam peran pemerintah dalam membatasi implementasi asas kebebasan berkontrak dalam sistem ekonomi liberal. Sunaryati Hartono berpendapat bahwa kaidah hukum baru yang muncul melalui rencana pembangunan pada zaman orde baru telah menyimpang dari kaidah hukum publik ataupun privat sehingga melahirkan suatu cabang hukum baru pula. Implementasi konsep hukum dan konsep ekonomi menimbulkan conflict of interest dalam upaya pelaksanaan pembangunan nasional.

Supremasi hukum harus ditegakkan melalui reformasi hukum secara substansi, struktur maupun kultur. Hampir bersamaan dengan gaung penghargaan terhadap Hak Asasi Manusia, kebebasan berpendapat menjadikan masyarakat memiliki pola pikir yang lebih kritis dan konstruktif sehingga melakukan fungsi kontrol juga terhadap pemerintah sehingga siapa - siapa yang sedang duduk pada kursi pemerintahan tidak melakukan hal hal yang melanggar hak - hak masyarakat tersebut.

Bukan hanya permasalahan dalam negeri, Indonesia juga harus menerima tantangan yang muncul sebagai hasil dari proses globalisasi ekonomi sehingga antar satu negara dengan negara yang lain seolah - olah taka da batasn lagi dalam melakukan kegiatan ekonomi dalam lingkup besar free trade. Dapat pula dibanyangkan bahwa daya saing ekonomi bukan lagi melawan pengusaha dalam negeri namun juga luar negeri secara internasional yang tak terbatas pada kegiatan usaha barang maupun jasa saja melainya seluruhnya. Logika nya daya saing yang begitu tinggi tersebut menuntut pemerintah yang harus tetap dapat melindungai pelaku usaha mikro kecil dan menengah yang tak hanya bersaing pada pasar internasional namun juga pasar domestik. Namun demikian menjadi dilematis pula ketika kebijakan suatu negara tak boleh bertentangan dengan ketentuan internasional yang bahkan sampai sekarang masih muncul polemik.

Ketentuan - ketentuan internasional yang telah disepakati bersama mewajibkan negara - negara anggota untuk mendukung dan patuh terhadap ketentuan tersebut. Perlindungan terhadap industri kecil domestik melalui hambatan perdagangan (subsidi dan

${ }^{17}$ Ibid. 
non tariff) harus benar - benar dihindari agar tidak dituntut secara internasional. Revolusi teknologi informasi tak dapat dibendung sehingga yang harus dilakukan adalah dengan menghadapinya, permasalahan - permasalahan e-commerce, Teknologi Informasi (IT), aktifitas kejahatan yang dilakukan di dunia maya (cyber crime), pasar online, distance selling atau penjualan jarak jauh, setifikat digital, korupsi, Tindak Pidana Pencucian Uang (Money Loundring), terorism serta berlakunya ASEAN Free Trade Area (AFTA), diperlukan readiness of regulation yang dapat disesuaikan dengan kebutuhan zaman seperti aturan hukum mengenai arbitrase dan alternative dispute resolution, Perseroan Terbatas, Perusahaan Multinasional, AFTA, antidumping, antitrust, monopoli dan persaingan usaha tidak sehat, perlindungan hukum terhadap konsumen, hukum laut/kemaritiman, hukum udara dan ruang angkasa, ius constituendum hukum komersial, perlindungan terhadap Hak Kekayaan Intelektual (HKI), teknologi informasi dan komunikasi, cyber law, serta ketentuan - ketentuan international tentang perdagangan dan ekonomi yang harus disesuaikan dengan substansi hukum nasional melalui ratifikasi. Readiness of regulation tersebut harusnya dapat melindungi industri domestik dan juga tanpa menimbulkan hambatan perdagangan bain subsidi maupun non tarif.

Fokus terhadap meningkatan taraf hidup masyarakat di Indonesia dapat ditandai dengan tumbuhnya iklim investasi, upaya peningkatan pendapatan perkapita penduduk yang mana peningkatan tersebut berlangsung dengan jangka panjang ${ }^{18}$. Gna menghindari ketertinggalan dengan negara - negara lain, pembangunan ekonomi menjadi sebuah keharusan yang diupayakan. Namun demikian harus sejalan dan selaras dengan pembangunan hukum di Indonesia yang memadai sehingga Welfare state dapat terwujud dan bukan lagi menjadi hayalan belaka suatu bangsa.

Baldwin mengukur membangunan ekonomi suatu negara yaitu melalui pendapatan perkapita penduduknya. Melalui hasil tabulasi data yang disusun oleh Badan Pusat Statistik (BPS), Pada tahun 2016 perekonomian Indonesia diukur berdasarkan Produk Domestik Bruto (PDB) atas dasar harga yang berlaku mencapai Rp 12.406,8 triliun. Sementara pendapatan per kapita menduduki angka Rp 51,89 juta, setara US\$ 3.876,8 pada Tahun 2017. ${ }^{19}$ Meskipun tidak signifikan namun dilihat dari diagram berikut pendapatan perkapita penduduk Indonesia mengalami peningkatan tujuh tahun terakhir (2010-2016) sebagaimana tergambar dalam diagram berikut:

PDB Per Kapita Indonesia (2010-2016)

50 Juta

45 Juta

$\begin{array}{lll}\overline{{ }^{18} \mathrm{~S}} & & 40 \text { Juta } \\ \mathrm{Vol} & & \\ { }^{19} \mathrm{H} & & \\ \text { eko } & & \end{array}$

30 Juta

25 Juta
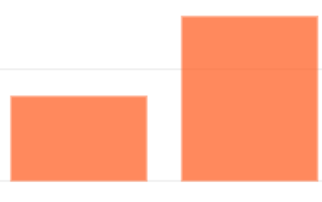

2010

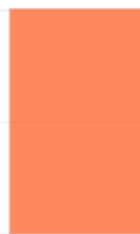

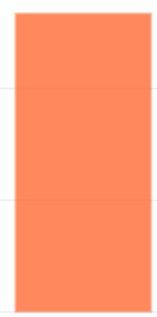

2013

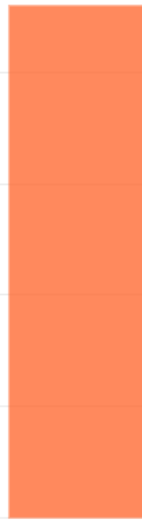

l, No. 4, 96-juta- 


\section{Peran Hukum dalam Pembangunan Nasional ditinjau dari Prinsip Ekonomi Kerakyatan}

Soeharto Prawiro Kusumo memiliki pemikiran bahwa terdapat beberapa ciri - ciri konsep demokrasi ekonomi atau ekonomi kerakyatan ${ }^{20}$ yaitu: pertama, partisipasi secara aktif seluruh lapisan masyarakat baik itu pengusaha/produsen, konsumen bahkan sampai dengan tenaga kerja dalam kegiatan ekonomi bangsa harus dilindungi hak - hak nya oleh negara melalui hukum yang brelaku. Kedua, Upaya menyuburkan usaha - usaha kecil, mikro serta mengurangi kemiskinan dan pemberdayaan usaha mikro, kecil dan menengah (UMKM), serta badan usaha koperasi koperasi termasuk perhatian terhadap petani dan nelayan, merupakan suatu pengutamaan dalam mengembangkan sistem demokrasi ekonomi atau ekonomi kerakyatan. Dukungan terhadap beberapa kelompok penduduk yangmemiliki keterbatasaan oleh keadaan dapat dilakukan untuk meningkat kemampuannya agar dapat memanfaatnya akses yang terbuka. Dukungan oleh pemerintah sangatlah diperlukan melalui upaya konkret berupa dan kemudahan dalam permodalan, informasi pasar, dan teknologi tepat guna.

Ketiga, intervensi oleh pemerintah diperlukan guna menciptakan iklim persaingan usaha yang sehat. Memberikan kemudahan kepada pelaku usaha mikro kecil dan menengan bukan atas dasar belas kasihan melaikan menumbuhkan pasar yang kompetitif sehingga menstimulasi UMKM untuk dapat selalu survive dalam menjalankan kegiatan ekonomi. Keempat, memprioritaskan pembangunan ekonomi pedesaan, daerah tertinggal, terdepan, dan terluar dan termasuk daerah terbelakang lainnya. Hal tersebut dapat pula sekaligus memecahkan permasalahan membludaknya penduduk perkotaan karena arus urbanisasi. Penduduk desa yang diberdayakan akan merasa tak perlu lagi merantau ke kota - kota besar jika di desa/daerahnya pertumbuhan ekonomi dapat mencukupi kebutuhan.

Kelima, kelestarian lingkungan hidup menjadi fokus selanjutnya yakni dengan membatasi eksploitasi yang berlebihan terhadap sumber daya alam yang ada sehingga kelestarian lingkungan tetap terjaga. Isu lingkungan menjadi isu global mendapati bahwa bumi sudah terlalu banyak dieksplotasi tanpa memikirkan keberlangsungan lingkungan

\footnotetext{
${ }^{20}$ Soeharto Prawiro Kusumo, Ekonomi Rakyat : Konsep Kebijakan dan Strategi, (Yogyakarta : BPFE,tth), hlm. 4.
} 
yang ada. Khususnya di Indonesia yang memiliki sumber daya alam yang melimpah serta perlu dibarengi dengan pengakuan hak ulayat dan hak rakyat setempat agar tidak memunculkan kondisi masyarakat yang merasa terusir dari tanah sendiri.

Secara yuridis prinsip - prinsip dasar ekonomi kerakyatan dapat kita temukan dalam Pasal 33 Undang - Undang Dasar Negera Republik Indonesia 1945 diantaranya adalah;

a. Prinsip kekeluargaan. Penjelasan Undang-Undang Dasar Negera Republik Indonesia 1945 menyatakan bahwa perekonomian disusun sebagai usaha bersama berdasarkan atas asas kekeluargaan. Meskipun digunakan sebagai acuan dalam pelaksanaan usaha BUMN dan BUMS, BUMD namun badan usaha yang paling sesuai dengan prinsip ini adalah Koperasi. Sebagai soko guru perekonomian, predikat yang disematkan pada badan usaha koperasi untuk pelaksanaan sampai saat ini belum juga menggambarkan Koperasi sebagai soko guru perekonomian. Masalah yang utama adalah kesadaran masyarakat Indonesia untuk berkoperasi sangat rendah. Karena Badan Usaha Koperasi telah kalah pamor dengan Badan Usaha lain seperti comanditer venotschaap (CV) ataupun perseroan terbatas (PT).

b. Prinsip keadilan. Pelaksanaan ekonomi kerakyatan harus dapat mewujudkan keadilan dalam masyarakat. Sistem ini diharapkan bisa memberikan peluang yang sama kepada semua anak bangsa generasi penerus, baik itu konsumen, produsen/pengusaha maupun sebagai tenaga kerja. Hapusnya stigma mengenai perbedaan suku, agama dan gender, semuanya sama dalam lapangan ekonomi;

c. Prinsip pemerataan pendapatan, telah menjadi rahasia umum bahwa di Indonesia ketimpangan pendapatan masyarakat Indonesia sangatlah besar. Upaya pertumbuhan ekonomi dengan mengabaikan pemerataan pendapatan sama saja dengan sia - sia. Justru hal tersebut akan mempersubur kapitalisasi di Indonesia sehingga pemerataan pendapatan menjadi mustahil untuk dicapai. Sehingga prinsip pemerataan pendapatan ini sangatlah diperlukan;

d. Prinsip keseimbangan antara kepentingan individu dan kepentingan masyarakat, Pasal 27 ayat (2) Undang - Undang Dasar Negera Republik Indonesia 1945 menyatakan bahwa tiap - tiap warga negara berhak atas pekerjaan dan penghidupan yang layak bagi kemanusiaan. Hal itu meng-isyaratkan bahwa kepentingan pribadi/individu merupakan hal yang harus mendapat prioritas. Namun demikian kepentingan pribadi/individu pun tidak boleh mengabaikan kepentingan masyarakat. Sehingga sinergi antara kepentingan individu dengan kepentingan masyarakat dapat terwujud;

e. Prinsip kerja sama atau jaringan, perekonomian menjadi kuat merupakan bentuk kerja sama yang kuat pula oleh para pelaku ekonomi baik konsumen, produsen maupun tenaga kerja. Pelaku usaha kecil akan sangat terbatu dengan adanya kerja sama yang bagus oleh pelaku usaha skala besar.

Pelaksanaan kelima prinsip tersebut mutlak harus dilakukan dalam upaya peningkatan pembangunan ekonomi nasional. Hukum menyumbang peran juga dalam peningkatan pembangunan nasional tersebut melalui produk hukum yang dapat melindungi 
kepentingan para pelaku ekonomi dengan berlandaskan ekonomi kerakyatan. Jika dicermati satu persatu sebenarnya hukum tak hanya berperan dalam sektor ekonomi saja melainkan sektor - sektor lain yang dapat mendukung pembangunan nasional. ${ }^{21}$

Hukum adalah "alat perubahan sosial" menurut pandangan Roscoe Pound Pandangan Roscoe Pound tersebut, dalam hal ini ingin menjelaskan bahwa perubahan yang ada dalam masyarakat, dapat didahuluioleh hukum. Pun demikian suatu keadaan yang sebelumnya tidak ada menjadi ada dapat menggunakan hukum untuk melakukan rekayasa. Muncul 4 macam fungsi hukum, yakni:
a. sebagai pemelihara ketertiban;
b. sebagai sarana pembangunan;
c. sebagai sarana penegak keadilan; dan,
d. sebagai sarana pendidikan masyarakat.

Keempat fungsi itu hukum diatas sesungguhnya saling berkaitan dan tak dapat dipungkiri bahwa proses pembangunan membutuhkan hukum sebagau suatu sarana yang amat penting.

Mengikuti arus globalisasi sangatlah penting agar kita tidak tertinggal oleh negara negara lain. Pesatnya perkembangan perekonomian internasional sebagaimana disampaikan sebelumnya melahirkan pula ketentuan - ketentuan internasional bidang perekonomian yang wajib diselaraskan oleh kebijakan masing - masing negara anggota konvensi internasional tersebut. Perkembangan perekonomian global memberikan dampak positif dan juga negatif bagi Indonesia sebagai negara berkembang. Dampak positifnya adalah Indonesia memiliki akses luas dan sama dalam bidang perdagangan internasional. Disisi lain dampak negatifnya adalah Indonesia diharuskan emiliki kesiapan untuk menghadapi ketentuan - ketentuan perdagangan internasional sepetai free trade, equality serta recipority dalam kaitannya melindungi pelaku usaha kecil, mikro menengah dalam bersaing.

Indonesia dihadapkan pada berbagai penuntasan persoalan hukum yang harus tetap diselesaikan. Hal tersebut merupakan efek lain dari globalisasi ekonomi selain tuntutan sistem hukum nasional yang disesuaikan dengan globalisasi ekonomi. ${ }^{22}$ Hukum ekonomi berfungsi mengatur sekaligus membatasi kegiatan ekonomi. Hukum ekonomi lahir dari meningkatnya pertumbuhan perekonomian global. Sistem pembangunan perekonomian yang diatur oleh kebijakan - kebijakan hukum diharapkan tetap memperhatikan kepentingan dan hak dari masyarakat sebagai pelaku ekonomi. ${ }^{23}$

\section{PENUTUP}

\footnotetext{
${ }^{21}$ Ade Manan S, Aspek Hukum dalam Ekonomi Global, Ghalia Indonesia, Bogor: 2005, hlm. 8.

${ }^{22}$ Ngadino, "Peranan Hukum dalam Globalisasi Ekonomi", Jurnal Pembaharuan Hukum, No.1, Vol. 1, 2014, hlm, 59-65.

${ }^{23}$ Elsi Kartika S, dan Advendi Simangunsong, Hukum dalam Ekonomi, Gramedia Widiasarana Indonesia, Jakarta: 2005, hlm. 4.
} 
Sistem Ekonomi nasional Indonesia menganut asas kekeluargaan, berkedaulatan rakyat, bermoral Pancasila, serta menunjukkan keberpihakan terhadap ekonomi rakyat. Pembangunan ekonomi Indonesia seharusnya dilakukan tanpa mengesampingkan sistem ekonomi nasional sehinggal era globalisasi yang tak dapat ditampikkan oleh Indonesia pun juga harus disesuaikan dengan sistem ekonomi kerakatan yang memihak kepada ekonomi rakyat Indonesia. Tak juga dapat dipungkiri jika dalam era globalisasi prinsip - prinsip liberalism secara halus bisa memasuki Indonesia, pun demikian hukum harus mengambil peran agar dapat tetap memposisikan sistem ekonomi kerakyatan sebagai sistem ekonomi nasional yang tidak akan dapat dikesampingkan begitu saja.

Pengembangan Badan Usaha berbentuk Koperasi sebagai soko guru perekonomian, pengembangan BUMN, pemanfataan sumber daya alam yakni bumi, air dan segala kekayaan yang terkandung di dalamnya bagi sebesar - besar kemakmuran rakyat, pemenuhan hak setiap warga negara untuk mendapatkan pekerjaan dan penghidupan yang layak, pengelolaan anggaran negara untuk kesejahteraan rakyat, menjaga stabilitas moneter merupakan "Pekerjaan Rumah" besar pemerintah yang dapat diakomodir melalui hukum sehingga hukum memiliki peran yang penting dalam pembangunan nasional dengan mengacu para prinsip ekonomi kerakyatan.

\section{DAFTAR PUSTAKA}

\section{Buku}

A. Z. Fachri Yasin, dkk, Petani, Usaha Kecil Dan Koperasi Berwawasan Ekonomi Kerakyatan, Unri Press, Pekanbaru: 2002.

Abdul R. saliman, Hukum Bisnis untuk Perusahaan :Teori dan Contoh Kasus, Prenadamedia Group, Jakarta: 2015.

Ade Manan S, Aspek Hukum dalam Ekonomi Global, Ghalia Indonesia, Bogor: 2005.

Adi Sulistyono dan Muhammad Rustamaji, Hukum Ekonomi sebagai Panglima, Masmedia Buana Pustaka, Sidoarjo: 2009.

Aminuddin Ilmar, Konstruksi Teori dan Metode Kajian Ilmu Hukum, Hasanuddin University Press, Makassar: 2009.

Baswir Revrisond, Tiada Ekonomi Kerakyatan Tanpa Kedaulatan Rakyat, Pustaka Pelajar, Yogyakarta: 1995.

Elsi Kartika S, dan Advendi Simangunsong, Hukum dalam Ekonomi, Gramedia Widiasarana Indonesia, Jakarta: 2005.

Gunarto Suhardi, 2002, Peranan Hukum Dalam Pembangunan Ekonomi, Universitas Atmajaya, Yogyakarta: 2002. 
Mubaryo, Reformasi Sistem Ekonomi: Dari Kapitalis Menuju Ekonomi Kerakyatan, Aidtya Media, Yogyakarta, 1999.

Penduduk Miskin), Adicita Karya Nusa ,Yogyakarta: 2006.

Rachmadi Usman, Hukum Ekonomi dalam Dinamika, Djambatan, Jakarta: 2014.

Simarmata, D. A, Reformasi Ekonomi, Lembaga Penerbit Fakultas Ekonomi UI, Jakarta: 1998.

T. Mulya Lubis, ed.Peran Hukum dalam Perekonomian di Negara Berkembang, Yayasan Obor Indonesia, Jakarta,1986.

Y. Sri Susilo, Peranan Hukum dalam Pembangunan Ekonomi, Universitas Atma Jaya Yogyakarta (UAJY), Yogyakarta: 2002

\section{Jurnal}

Ngadino, "Peranan Hukum dalam Globalisasi Ekonomi”, Jurnal Pembaharuan Hukum, No.1, Vol. 1, 2014.

Sukardi, "Peran Penegakan Hukum dalam Pembangunan Ekonomi", Jurnal Hukum dan Pembangunan, No. 4, Vol. 46, 2016.

\section{Sumber Lainnya}

Dewa Ayu, M. K. P. S dan I Gusti, N. P, "Fungsi Hukum dalam Pembangunan Ekonomi", file://C:/Users/user/Downloads/6246-10303-1-SM.pdf.Hal:1-2., (Diakses pada 13/1/2019).

Fitri N. Heriani, "Tujuh Perjanjian Perdagangan Indonesia Ini akah diratifikasi oleh Indonesia” 2018, https://www.hukumonline.com/berita/baca/lt5bea2c400d717/7perjanjian-perdagangan-internasional-ini-akan-diratifikasi-indonesia.diakses (Diakses pada 22/ 2019).

Humas Sekretariat Kabinet Republik Indonesia, 2019, http://setkab.go.id/pendapatan-perkapita-rp-4796-juta-ekonomi-indonesia-2017-tumbuh-502-persen/.diakses. (Diakses pada 19/1/2019)

Maryanto, "Pengaruh Globalisasi dalam Pembangunan Ekonomi Indonesia", 2011 http://maryanto.blog.unissula.ac.id/2011/10/07/pengaruh-globalisasi-terhadap-hukumekonomi-indonesia/.diakses. (Diakses pada 22/1/2019).

Statistical year of Indonesia 2018 Katalog 1101001 Badan Pusat Statistik Indonesia. (Yogyakarta : BPFE,th), 2018. 